FITRAH Jurnal Kajian Ilmu-ilmu Keislaman

Vol. 03 No. 1 Juni 2017

e-ISSN : 2460-2345, p-ISSN: 2442-6997

Web: jurnal.iain-padangsidimpuan.ac.id/index.php/F

\title{
PERAN POLITIK PENDIDIKAN ISLAM \\ DALAM MENYUSUN KURIKULUM PENDIDIKAN AGAMA ISLAM MENUJU PENDIDIKAN ABAD XXI
}

\author{
H. IHWANUDDIN, M.Pd \\ Kepala Sekolah SMA Negeri 1 Sayur Matinggi Kabupaten Tapanuli Selatan \\ Email:ihwanuddinpulungan@gmail.com
}

\begin{abstract}
Islamic education of curriculum is soft ware humanist mindset of Indonesian society which must be organized and perfected. Islamic education of curriculum given to each learner even educators in order to create a pleasant learning aqidah, syariah (Iman, Islam, Ihsan) and appreciate, that education in the XXI century reached the meaningfulness and even heat balance and the cruel demands of a globalized world. In the context of globalization, education should be able to maintain the cultural and national identity in the midst of the incessant onslaught of diverse cultures and civilizations of other nations. For this the policy makers must do the hard work to make education a format value and a reflection of civilization. Political Islamic education must play in order to manifest the demands of the XXI century. Political Islamic education spawned new policies in Islamic education that represents the ideology and philosophy of a nation so that the people educated and motivated to face the XXI century as evidence of their efforts and ways of thinking of the nation's most beautiful quality. Political Islamic education should be raised and echoed in every activity of life, especially in taking any educational policy. Pursued education policy serve as an instrument in addressing any educational activity that is easily understood and implemented education of every citizen education. Political Islamic education serve as the basis of philosophical and ideological education in carrying out activities to develop Islamic education of curriculum. The Islamic education of curriculum oriented education model and view in education, namely God's creatures by nature. Islamic education of curriculum beings live, should be able to establish, maintain, and develop their life. In this case the position of education is expected to build the process of education.
\end{abstract}

Keywords: Education, Islamic education of curriculum, century XXI.

\begin{abstract}
Abstrak
Kurikulum Pendidikan Agama Islam merupakan soft ware pola pikir masyarakat Indonesia yang harus ditata dan disempurnakan. Untuk itu kurikulum Pendidikan Agama Islam layaklah diberikan kepada setiap peserta didik bahkan pendidik agar tercipta suasana pembelajaran yang mempunyai podasi akidah, syariah (iman, Islam dan ihsan), sehingga pendidikan di abad XXI mencapai kebermaknaan dan keseimbangan
\end{abstract}


FITR AH Jurnal Kajian Ilmu-ilmu Keislaman

Vol. 03 No. 1 Juli 2017

\begin{abstract}
sekalipun panas dan kejamnya tuntutan dunia yang mengglobal. Dalam konteks globalisasi, pendidikan harus mampu mempertahankan budaya dan jati diri bangsa di tengah-tengah gencarnya gempuran beragam budaya dan peradaban bangsa lain. Untuk ini para pengambil kebijakan mesti melakukan kerja keras guna menjadikan pendidikan sebagai format nilai dan cerminan peradaban. Politik pendidikan Islam harus berperan guna mengejawantah tuntutan abad XXI. Politik pendidikan Islam yang melahirkan kebijakan-kebijakan baru di bidang pendidikan yang mewakili ideologi dan filosofi suatu bangsa sehingga bangsa terdidik dan tergerak untuk menghadapi abad XXI sebagai bukti adanya upaya dan cara untuk memikirkan bangsa mecapai kualitas terindah. Politik pendidikan Islam mesti dibesarkan dan digaungkan dalam setiap aktivitas kehidupan khususnya dalam mengambil setiap kebijakan pendidikan. Politik pendidikan Islam diupayakan dijadikan sebagai instrumen dalam menyikapi setiap aktivitas pendidikan agar pendidikan mudah dipahami dan dilaksanakan setiap warga pendidikan. Politik pendidikan Islam dijadikan sebagai landasan filosofis dan ideologis dalam menjalankan aktivitas pendidikan untuk menyusun kurikulum Pendidikan Agama Islam. Kurikulum Pendidikan Agama Islam merupakan dasar pendidikan yang berorientasi dan memandang setiap dasar hidup harus terarah berdasarkan aqidah dan syariah, yakni makhluk ciptaan Tuhan dengan fitrahnya. Manusia sebagai makhluk hidup, harus mampu melangsungkan, mempertahankan, dan mengembangkan hidupnya. Dalam hal ini posisi pendidikan sangat diharapkan dapat membangun proses pendidikan.
\end{abstract}

Kata Kunci: Politik, Kurikulum Pendidikan Agama Islam, Abad XXI

\title{
PENDAHULUAN
}

Abad XXI merupakan abad yang mengglobal. Maraknya perkembangan kebudayaan, dan semakin heterogennya masyarakat menjadikan berbaurnya pola pikir dan pola sikap. Masyarakat yang berfikir di abad XXI mempunyai khazanah pola pikir yang berbeda, mulai dari latar pendidikan, ekonomi keluarga yang tidak merata hingga keutuhan dan kesatupaduan yang beragam. Hal ini pulalah yang dihadapi pada abad XXI. Abad XXI baru berjalan satu dekade, namun dalam dunia pendidikan Islam sudah dirasakan adanya pergeseran, dan bahkan perubahan pada tataran politik, filsafat, arah serta tujuannya. Tidaklah berlebihan bila dikatakan bahwa pendidikan Islam dipicu oleh lahirnya berbagai kebijakan, kemajuan serta pengetahuan dan kekuasaan. Maju mundurnya pendidikan Islam harus dibangun di atas pengetahuan dan kekuasaan. Dengan piranti pengetahuan bidang sains dan teknologi terutama dalam bidang cognitive science, bio-molecular, information technology dan nano- 
science kemudian menjadi kelompok ilmu pengetahuan yang mencirikan abad XXI. ${ }^{1}$ Agar ciri pengetahuan dan pendidikan abad XXI mampu menyatukan kesepahaman dan saling menghargai dibutuhkan adanya kurikulum Pendidikan Agama Islam.

Kurikulum Pendidikan Agama Islam. merupakan soft ware pola pikir masyarakat Indonesia yang harus ditata dan disempurnakan. Untuk itu kurikulum Pendidikan Agama Islam layaklah diberikan kepada setiap peserta didik bahkan pendidik agar tercipta suasana pembelajaran yang menyenangkan dan menghargai, sehingga pendidikan di abad XXI mencapai kebermaknaan dan keseimbangan sekalipun panas dan kejamnya tuntutan dunia yang mengglobal. Pada abad XXI terdapat berbagai kekhususan yang utama pertama terwujudnya masyarakat global yang menjadi kesepakatan antara bangsa, yaitu terbukanya mobilitas yang lebih luas antara satu negara dengan negara lain dalam berbagai hal. Kedua adalah abad ini akan lebih dikuasai oleh perkembangan ilmu dan teknologi yang makin canggih dan berpadu pula dengan ilmu sosial dan humaniora. Karena hal inilah penting kiranya para pengambil kebijakan atau para politisasi pendidikan yang ada di Dewan Perwakilan Rakyat (DPR) di Kementerian Pendidikan dan Kementerian Agama supaya merumuskan kurikulum Pendidikan Agama Islam. sehingga dunia abad XXI tumbuh secara harmonis dan dinamis, inspiratif. Harmonis dalam aspek kesepakatan dan dinamis dalam perkembangan keilmuan.

Dalam konteks globalisasi, Pendidikan Agama Islam.harus mampu mempertahankan budaya dan jati diri bangsa di tengah-tengah gencarnya gempuran beragam budaya dan peradaban bangsa lain. Holger Daun menyebutkan bahwa: Now globalization processes add to this challenge in that they result in an increasing demand for competitive and technical skills. (Sekarang proses globalisasi menambah tantangan di mana mengakibatkan peningkatan permintaan untuk keterampilan kompetitif dan adanya beberapa keahlian teknis). ${ }^{2}$ Sebagai sebuah negara yang kaya akan suku budaya yang beraneka ragam (heterogen), Indonesia harus mampu menjadi bangsa yang mandiri dalam arti sanggup memenuhi berbagai kebutuhan masyarakat sesuai dengan

${ }^{1}$ Badan Standar Nasional Pendidikan. Versi 1.0. Paradigma Pendidikan Nasional Abad XXI (Jakarta: BSNP, 2010), h.20

${ }^{2}$ Holger Daun. Reza Arjmand \& Geoffrey Walford. (Chapter One). Muslims and Education In a Global Context. Educational Strategies Among Muslims In The Context Of Globalization Some National Case Studies, Volume 3, ISBN. 9004136754. (Boston: Brill Leiden, 2004), h.5 
FITR AH Jurnal Kajian Ilmu-ilmu Keislaman

Vol. 03 No. 1 Juli 2017

keterampilan-keterampilan yang bersifat teknik sehingga mampu berkompetisi dengan siapapun dan di negara mana pun. Untuk itu sejak Sekolah Dasar hingga Perguruan Tinggi penting diberikan Pendidikan Agama Islam. Sebagai mata pelajaran wajib, guna kompetisi yang berlangsung adalah kompetisi yang saling membangun. Melalui Pendidikan Agama Islam. semua perangkat pembelajaran dirancang sedemikian rupa dan dijadikan sebagai pedoman penyelenggaraan pendidikan untuk mencapai tujuan pendidikan, sebagaimana bunyi pasal 1 ayat 19 Undang-Undang Sistem Pendidikan Nasional (Sisdiknas) No. 20 tahun 2003 yang berbunyi: Kurikulum adalah seperangkat rencana dan pengaturan mengenai tujuan, isi dan bahan pelajaran serta cara yang dingunakan sebagai pedoman penyelenggaraan kegiatan pembelajaran untuk mencapai tujuan pendidikan tertentu. ${ }^{3}$

Dirumuskannya definisi kurikulum dalam Undang-Undang Sistem Pendidikan Nasional (Sisdiknas) No. 20 tahun 2003 adalah sebagai landasan ideal bagi semua masyarakat Indonesia yang peka terhadap pendidikan agar melahirkan kurikulum yang berbasis humanis. Kurikulum Pendidikan Agama Islam adalah penyelenggaraan pendidikan berdasarkan kekhasan menghargai dan mengasihi antara sesama warga pendidikan sehingga aspirasi dan potensi dapat saling diejawantah dan terbangunlah hati yang tulus, sikap yang luhur serta aktivitas yang menyenangkan. Dengan harapan pendidikan dapat berjalan sesuai dengan kebutuhan dan harapan setiap masyarakat. Hal ini sebagai perwujudan dalam berbuat baik. Melalui Kurikulum Pendidikan Agama Islam mengajak setiap insan berbuat baik, sesuai dengan firman Allah SWT: Al-Qasas 77.
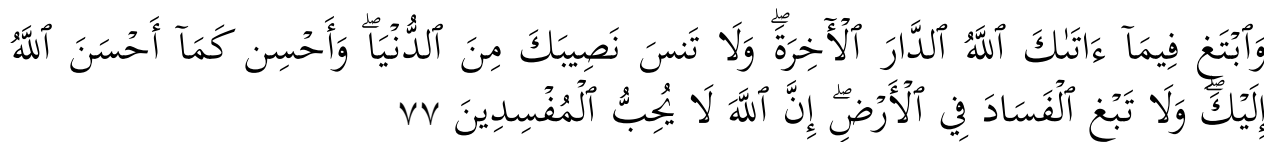

Artinya: Dan carilah pada apa yang telah dianugerahkan Allah kepadamu (kebahagiaan) negeri akhirat, dan janganlah kamu melupakan bahagianmu dari (kenikmatan) duniawi dan berbuat baiklah (kepada orang lain) sebagaimana Allah telah berbuat baik, kepadamu, dan janganlah kamu berbuat kerusakan di (muka) bumi. Sesungguhnya Allah tidak menyukai orang-orang yang berbuat kerusakan.

Kurikulum Pendidikan Agama Islam sebagai bagian dari rangkaian pembangunan bangsa dapat melakukan berbagai kebijakan serta pendekatan-

${ }^{3}$ Departemen Pendidikan Nasional Republik Indonesia, Undang-Undang Republik Indonesia No.20 Tahun 2003 tentang Sistem Pendidikan Nasional (Jakarta: Departemen Pendidikan Nasional Republik Indonesia, 2003), h. 7. 
pendekatan dalam menyahuti arus globalisasi dalam menghadapi abad XXI melalui perbuatan baik. Pendidikan Agama Islam memainkan peran melalui praktisi pendidikan baik berperan sebagai aktor, peretas politik pendidikan Islam. Paul Kennedy menunjukkan berbagai faktor yang berperan sebagai pendorong dan penghambat negara dalam merespons proses perubahan seperti: struktur sosial politik, sikap kultural dan pendidikan, keyakinan agama, pengalaman sejarah dan kemahiran ekonomi (economic powers). ${ }^{4}$

Dalam hal ini diketahui bahwa proses pendidikan Islam berperan penting dalam membentuk perilaku politik masyarakat. Begitu juga sebaliknya, proses politik Islam membawa dampak besar pada karakteristik pendidikan agama di negara tersebut. Ada hubungan erat dan dinamis antara pendidikan dan politik pendidikan Islam. Hubungan tersebut adalah realitas empiris yang telah terjadi sejak awal perkembangan peradaban manusia dan menjadi perhatian ilmuwan. Hubungan timbal balik antara pendidikan dan politik pendidikan Islam dapat terjadi melalui tiga aspek, yaitu pembentukan sikap kelompok (group attitude), masalah pengangguran (unemployment), dan peranan politik kaum cendekia (the polical role of the intelligentsia). ${ }^{5}$

Keterikatan antara politik pendidikan Islam dan kurikulum pendidikan agama Islam begitu kuat dan hal inilah yang penulis telusuri bahwa antara pendidikan Islam dan politik Islam dapat membangun hal-hal baru dengan senantiasa up-date terhadap zaman di mana pendidikan agama Islam dan politik Islam itu berkembang. Untuk itu diharapkan para politik pendidikan agama Islam, atau para pembuat kebijakan dalam bidang pendidikan agama Islam selayaknyalah memikirkan untuk menyusun kurikulum pendidikan agama Islam sehingga persoalan-persoalan di setiap peradaban dapat diantisipasi. Banyak persoalan pendidikan dipahami salah kalau dingunakan hanya teoriteori pendidikan. Hal ini dikarenakan hanya menggunakan frame ilmu pendidikan Islam tidak melihat akar permasalahan. Akar permasalahan pendidikan Islam tidak hanya di sekolah tapi di tingkat pengambil kebijakan di pusat-pusat kekuasaan politik Islam itu sendiri . Dalam hal ini ada sesuatu yang menarik dalam pendidikan Islam menghadapi abad XXI yaitu: politik pendidikan Islam yang baik selayaknyalah memberikan sumbangan kepada

${ }^{4}$ Paul Kennedy. (Terj). Menyiapkan Diri Menghadapi Abad Ke-21(Jakarta: Yayasan Obor Indonesia, 1995) h. XIV.

${ }^{5}$ M. Sirozi. Politik Pendidikan, Dinamika Hubungan antara Kepentingan Kekuasaan dan Praktik Penyelenggaraan Pendidikann (Jakarta: Grafindo Persada, 2010), h.7. 
FITR AH Jurnal Kajian Ilmu-ilmu Keislaman

Vol. 03 No. 1 Juli 2017

bangsa dengan menyusun kurikulum Pendidikan Agama Islam dalam membangun pendidikan dalam menghadapi abad XXI?.

Untuk itu dalam tulisan ini diungkapkan bahwa politik pendidikan Islam yang baik adalah apabila penguasa memanfaatkan pendidikan untuk kekuasaannya di mana merujuk pada general politik. Untuk mengembangkan jawaban permasalahan tersebut politik pendidikan Islam harus kerja keras menyusun kurikulum Pendidikan Agama Islam.

\section{PEMBAHASAN}

\section{Pengertian Politik Pendidikan Islam}

Pendidikan dan politik pendidikan Islam adalah dua elemen penting dalam sistem sosial politik di setiap negara. Pengintegrasian pendidikan dan politik pendidikan Islam, keduanya terus saling terkait. Pendidikan Islam menyangkut proses transmisi ilmu pengetahuan dan budaya, serta perkembangan keterampilan dan pelatihan untuk nilai-nilai yang berlandaskan syar'i. Politik pendidikan Islam berkenaan dengan praktik kekuasaan, pengaruh dan otoritas yang berhubungan dengan pembuatan keputusan-keputusan otoritatif tentang alokasi nilai-nilai dan sumber daya. Politik pendidikan Islam dan pendidikan Islam sarat dengan proses pengalokasian dan pendistribusian nilai-nilai dalam masyarakat, maka tidaklah sulit untuk memahami bahwa pendidikan Islam dan politik pendidikan Islam adalah dua perangkat aktivitas yang terus berinteraksi. Kemudian dengan kesetiaan politik pendidikan Islam, sebuah masyarakat berkembang yang pada akhirnya bergerak maju ke perilaku politik yang terbangun atas dasar kewilayahan yang islami. ${ }^{6}$

Robert W.Hefner seorang orientalis menyebutkan politik pendidikan Islam berkontribusi terhadap pendidikan agama Islam di mana budaya dan politik Islam itu sendiri berperan. Peran politik pendidikan Islam sangat besar dalam membangun pendidikan di negara yang mayoritas Islam. Pembangunan pendidikan Islam mulai dari perkembangan peradaban bangsa menuju pendidikan perkembangan Islam abad XXI yakni pendidikan dunia yang dinamis, modernis namun tetap diharapkan menjadi pendidikan yang berdasarkan nilai-nilai religiusitas. The contributors aim to provide a sense of just where education is going by examining where, culturally and Islamic politically speaking,

${ }^{6}$ Frank McGlynn \& Athur Tuden. Pendekatan Antropologi Pada Perilaku Politik (Jakarta:UPI Press, 2000), h.9. 
it has come from. (Para kontributor bertujuan untuk memberikan makna di mana pendidikan akan terakui jika, budaya dan politik Islam berbicara). ${ }^{7}$

Perkembangan politik Islam di Indonesia, membuktikan adanya kepedulian terhadap hubungan pendidikan dan masyarakat Islam serta berupaya untuk memajukan wilayah Indonesia baik dari sudut perkembangan penduduknya yang paham terhadap pembangunan pendidikan bangsa yang mayoritas muslim. Dengan demikian politik pendidikan Islam mampu berpartisipasi dan menempatkan posisi dalam pembangunan pendidikan agama Islam di Indonesia khususnya menghadapi abad XXI. Partisipasi politik Islam dalam politik pendidikan Islam di Indonesia dapat diketahui dari sistem politik Islam di Indonesia di mana sudah berupaya memisahkan jabatan politik dan jabatan birokrasi dengan melembagakan satu doktrin netralitas politik bagi para administrator dan agama harus dinomor satukan. ${ }^{8}$

Hal ini membuktikan bahwa adanya kesadaran bahwa kebijakankebijakan pendidikan dibidangi oleh para ahli-ahli pendidikan yang jelas kelembagaannya seperti: Pendidikan yang di bawah naungan Kementerian Pendidikan Nasional Kementerian Agama khusus membidangi madrasah. Demikian pula halnya dengan politik Islam adanya kesadaran akan peran penting pendidikan agama Islam dalam menentukan corak dan arah kehidupan politik yang berdasarkan islamisasi.

Dalam dua dekade terakhir, memasuki abad XXI dan pemberlakuan otonomi daerah, lingkungan politik pendidikan Islam di Indonesia telah mengalami beberapa perubahan penting. Perubahan tersebut ditandai oleh paling tidak tiga kecenderungan utama. Pertama, terjadinya perubahan peranan pemerintah pusat dan daerah dalam kebijakan pendidikan Islam . Kedua, muncul kembalinya kepentingan-kepentingan non kependidikan, terutama dari dunia bisnis, dalam wilayah negara. Hubungan antara pendidikan Islam dan politik pendidikan Islam, tidak bisa terlepas dari sejarah perkembangan pendidikan agama Islam masa lampau. Hubungan antara pendidikan Islam dan politik pendidikan Islam bukan sekedar hubungan saling mempengaruhi, tetapi juga hubungan fungsional. Lembaga dan proses pendidikan Islam menjalankan sejumlah fungsi politik Islam yang signifikan. Mungkin yang terpenting dari

${ }^{7}$ Robert W.Hefner, Hefner, Robert.W. Making Modren Muslims. The Politics Of Islamic Education In Southeast Asia (Honolulu: University Of Hawai'i Press, 2009), h.3.

${ }^{8}$ Michael Rush dan Phillip Althoff. Pengantar Sosiologi Politik (Jakarta: Rajawali Press.1990), h.184. 
FITR AH Jurnal Kajian Ilmu-ilmu Keislaman

Vol. 03 No. 1 Juli 2017

fungsi-fungsi tersebut bahwa sekolah-sekolah dan lembaga pendidikan Islam lainnya menjadi agen-agen sosialisasi politik Islam. Lembaga-lembaga pendidikan Islam seperti madrasah, pondok pesantren menjadi tempat di mana individu-individu, terutama anak-anak dan generasi muda, mempelajari sikapsikap dan perasaan tentang agama, dan sejenis peran politik pendidikan Islam yang diharapkan dari mereka.

Jelas diketahui bersama bahwa politik pendidikan Islam adalah proses membuat keputusan bersama yang elegant di mana mampu berkompromi menyelesaikan masalah-masalah pendidikan yang akhirnya mencapai suatu kebijakan yang menyenangkan di mana kebijakan itu suatu bentuk keputusan yang dibuat bersama demi kemaslahatan umat. Untuk itu penting kiranya para pembuat kebijakan pendidikan penting menyusun kurikulum Pendidikan Agama Islam agar semua rasa empati terbangun pada setiap peserta didik. Adanya rasa empati berarti masalah kebijakan pemerintah tentang full day pendidikan dapat berjalan karena tidak hanya full day materi tapi full day dalam kebersamaan dan full day dalam kebermaknaan. Full day dalam kebersamaan maksudnya keluarkanlah kebijakan politik pendidikan Islam adalah untuk menambahkan nilai-nilai spritual dan religiutas suatu bangsa. Full day kebermaknaan, diharapkan kerja dan aktivitas pembelajaran tersebut mendapat penghargaan, mulai penghargaan dari finansial serta penghargaan dengan loyalitas. Khususnya politik pendidikan dalam pendidikan abad XXI adalah keputusan yang up date dengan kondisi perkembangan pengetahuan dan kemajuan bangsa yang bersandarkan pada alquran dan sunnah.

Perkembangan pendidikan Islam di Indonesia bangsa merupakan salah satu indikator pembangunan pendidikan berhasil. Perkembangan pendidikan tersebut dapat dilihat dari pembaruan dan pembaharuan dalam bidang pendidikan Islam yang populer dikenal dengan reformasi pendidikan Islam. Reformasi pendidikan Islam dapat diwujudkan dengan reformasi kurikulum pendidikan aagama Islam. Untuk itu diharapkan setiap kurikulum pendidikan agama Islam yang hendak dilalui peserta didik mempunyai soft ware yang sesuai dengan aqidah, syariah. Kurikulum pendidikan agama Islam dalam pembelajaran diaplikasi pendidikan di lingkungan masyarakat yang Islami yakni Indonesia yang berfalsafah Pancasila yang memberikan nilai-nilai etika mewakili Indonesia sebagai negara beragama.

Menurut Riddel there are many different ways that one could categorise the different 'themes' of educational reform that have been prominent in 
developing countries. These can be divided broadly into three groups: (1) planning and efficiency reforms; (2) quality reforms; and (3) curricular reforms. He also points that there are no clear boundaries among these broad groups. (Ada banyak cara yang berbeda yang orang bisa mengkategorikan berbeda reformasi pendidikan yang telah menonjol di negara berkembang. Ini dapat dibagi secara luas menjadi tiga kelompok: (1) perencanaan dan efisiensi reformasi; (2)reformasi kualitas; dan (3) kurikuler reformasi). ${ }^{9}$

Ketiga cara tersebut bila dikaitkan dengan pendidikan Islam di Indonesia bahwa pemberian kebijakan dalam mereformasi pendidikan Islam merupakan salah satu faktor yang berpengaruh dalam perkambangan pendidikan Islam. Reformasi pendidikan Islam berupaya mengejawantah merencanakan pendidikan dalam mengatasi perkembangan dan persoalan-persoalan pendidikan sehingga terwujud reformasi kualitas dan juga reformasi tambahan lainnya bersifat islami. Reformasi Pendidikan Islam sebagai perencanaan dan efisiensi reformasi pendidikan sangat kelihatan jika tertulis dalam kurikulum Pendidikan Agama Islam. Kurikulum Pendidikan Agama Islam yang berbasis aqidah-syariah dan akhlakul karimah sebagai falsafah dasar dalam melakukan reformasi pendidikan Islam untuk menuju pendidikan Islam abad XXI.

Untuk menindaklanjuti agar penyusunan kurikulum Pendidikan Agama Islam. terlaksana penting merujuk kepada pembangunan pendidikan bidang kemajuan ekonomi Islam, kehidupan politik masyarakat Islam yang berpendidikan, administrasi hukum Islam, partisipasi massa yang Islami, pembinaan demokrasi Islam, mobilisasi dan kekuasaan serta perubahan sosial yang multi dimensi. ${ }^{10}$ Ketika pertama kali perhatian diarahkan pada masalahmasalah pertumbuhan ekonomi Islam maka penting pendidikan yang mengubah perekonomian yang berjalan lambat menjadi dinamis dengan pertumbuhan swasembada ahli-ahli ekonomi dengan cepat menunjukkan bahwa kondisi-kondisi sosial politik dapat memainkan peranan dalam membangun pendidikan bangsa. Para politikus pendidikan dengan serta merta mengaudit setiap kebutuhan pendidikan mulai dari kebutuhan peserta didik yang harus diperhatikan cost/siswa. Sehingga biaya untuk menyusun kurikulum Pendidikan Agama Islam. sangatlah terpenuhi. Dengan adanya perhatian para pengambil

9 Riddel. Reforms of educational efficiency and equity in developing countries: An overview. Compare, 28 (3), 227-292.The International Education Journal:Comparative Perspectives (South Australia: Press Adelaide, 2005), h. 6.

${ }^{10}$ Yahya Muhaimin \& Colin MacAndrews. Masalah-Masalah Pembangunan Politik. (Yogyakarta: Gadjah Mada University Press, 1995), h. 5-15. 
FITR AH Jurnal Kajian Ilmu-ilmu Keislaman

Vol. 03 No. 1 Juli 2017

kebijakan memberikan cost peserta didik dengan demikian tidak ada lagi alasan bahwa pendidikan tidak dinikmati setiap warga negara Indonesia. Jika setiap warga negara menikmati pendidikan dengan sungguh-sungguh diharapkan bangsa Indonesia jauh dari kebodohan dan kemiskinan. Hadis Rasulullah menyebutkan: Dari Anas bin Malik Radhiallahu'anhu bahwa Rasulullah Shallallahu'alaihi Wasallam bersabda:

$$
\text { كادَ الفَقْرُ أنْ يَكُوْنَ كُفْرًا }
$$

Hampir-hampir kefakiran (kemiskinan) itu menjadi kekafiran"

Kebodohan adalah pangkal kemiskinan, jika masyarakat Indonesia maju dan pintar dalam pendidikan dan peradaban maka setiap warga akan mampu bersaing dengan negara-negara yang lebih maju dan jaya dari Indonesia. (Kasus putri tukang becak dapat IPK: 3,96, Universitas Negeri Semarang Jurusan Akutansi memperoleh beasiswa ke Inggris yang diberikan Presiden RI Susilo Bambang Yudoyono). Asnawi mahasiswa asal Bangka meraih gelar Sarjana Ekonomi di Universitas Muhammadiyah Yogyakarta (UMY) lulus dengan IPK 3,39 dengan harus menempuh perjuangan panjang lantaran kuliah sambil berjualan gorengan. Saat ini Asnawi berusaha mencari informasi mendapatkan beasiswa ke luar negeri untuk meneruskan jenjang S2 ${ }^{11}$

Adanya diberikan beasiswa bagi para peserta didik ataupun beasiswa yang berprestasi berarti ada kepedulian untuk menjadikan anak bangsa maju dan pintar. Kepeduliaan tersebut merupakan bagian dari kerangka dasar Islam. Dengan begitu bila kurikulum Pendidikan Agama Islam. telah terpatri dalam setiap warga pendidkan maka keberlangsungan pendidikan akan meningkat. Memperhatikan pendidikan Islam berarti memperhatikan kelangsungan hidup bangsa melalui pendidikan itu sendiri. Sebagaimana Kuant-Tzu menyebutkan:

If you plan for a year, plant aseed

If for ten years, plant a tree.

If for a hundred years, teach the people.

When you shaw a seed once, you will reap a single harvest

When you teach the people, you will reap a hundred harvest

( $\{\mathrm{Jika}$ Anda berencana untuk satu tahun, tanamlah benih

Jika selama sepuluh tahun, tanamlah pohon.

Jika selama seratus tahun, didiklah manusia.

Bila Anda menabur benih sekali, Anda akan menuai panen tunggal

${ }^{11}$ Okezone. Lulus Sarjana, Penjual Gorengan Bawa Dagangannya Saat Wisuda, diterbitkan 15 Februari 2017. 
Ketika Anda mengajarkan orang, Anda akan menuai panen seratus\}). ${ }^{12}$

Kuant-Tzu membangun setiap bangsa dan setiap peserta didik bahwa pendidikan merupakan nilai modal manusia (human capital). Bangsa yang bagus ekonomi pendidikannya adalah yang menghargai kerja intelektual (intensive brain). Warga yang pintar dengan demikian merembes terhadap kehidupan politik masyarakat jika dapat berasumsi maka dapat menciptakan standar demokrasi yang baik dan berprestasi yang nantinya mampu membangun pendidikan yang elengant dan menguntungkan setiap masyarakat. Pendidikan agama Islamn adalah pendidikan yang kaya akan karimah, cinta akan kemanusiaan dan perhatian kepada setiap kebutuhan. Pendidikan agama Islam merupakan kehidupan yang khas dan ideal dari masyarakat yang terdidik hal ini sangat dibutuhkan modernisasi pendidikan Islam. Negara-negara yang maju adalah negara yang mampu melahirkan pelopor dan mode dalam setiap aktivitas kehidupan sosial masyarakat utamanya dalam pelopor pendidikan bangsa.

Adanya andil pelopor bangsa dalam membangun pendidikan maka dengan beberapa perubahan masyarakat telah ikut berpartisipasi aktif sehingga terbina demokrasi maka stabilitas bangsa pun akan terwujud. Stabilitas bangsa yang tertib, aman membuktikan bahwa ideologi bangsa tersebut solid dan tetap pada keyakinan kepastian epistemologis sehingga rakyat pun aman dalam menikmati pendidikan sehingga mampu membangun bangsa melalui pendidikan Islam.

Sebagaimana yang diungkapkan Gregory Minton, M. Alayne Sullivan a series of reality-based acts that must be conceived from two perspectives. The first is a stance of ideological belief, an epistemological certainty of a worldview holding that we must offer fair and good educational chances for all students-we believe this and act to build such a world.(Serangkaian berbasis realitas tindakan yang harus dipahami dari dua perspektif. Yang pertama adalah sikap keyakinan ideologis, kepastian epistemologis pandangan dunia memegang bahwa kita harus menawarkan kesempatan pendidikan yang adil dan baik untuk semua siswa-kami percaya ini dan bertindak untuk membangun dunia tersebut). ${ }^{13}$

${ }^{12}$ IBRD. The Challenge of Development (World Development Report: 1991), h.92.

${ }^{13}$ Gregory Minton, M. Alayne Sullivan. Educational Justice, Transformative Leadership Practices, and Special Needs Students International Journal of Education ISSN 1948-5476 Vol. 5, No. 4, www.macrothink.org/ije 190. 2013. 
FITR AH Jurnal Kajian Ilmu-ilmu Keislaman

Vol. 03 No. 1 Juli 2017

Bangsa yang maju adalah bangsa yang membangun pendidikannya. Pendidikan yang bagus adalah pendidikan yang sesuai dengan kondisi dan kebutuhan peserta didiknya (baca:masyarakat). Untuk memenuhi kebutuhan peserta didik tersebut para pengambil kebijakan memainkan peran dengan membuat sebuah lembaga yang mampu membentuk prinsif-prinsif dan praktek keadilan dalam pendidikan dan berdasar dengan keutuhan dan dapat diaplikasikan berdasarkan kurikulum Pendidikan Agama Islam.

We now briefly explore the conceptual underpinnings of our theoretical belief in social and educational justice .... has established core principles and practices of educational justice and transformative leadership. (Kita sekarang secara singkat menjelajahi dasar-dasar konseptual teoritis keyakinan kami dalam keadilan sosial dan pendidikan...... telah membentuk prinsip-prinsip inti dan praktek keadilan pendidikan dan kepemimpinan transformatif). ${ }^{14}$

Dengan berkembangnya pemikiran dan kemauan setiap pengambil kebijakan pendidikan mulai dengan mereformasi pendidikan Islam sebagai faktor yang paling akbar dalam menciptakan pembangunan pendidikan Islam yang diikuti dengan kondisi memperhatikan kurikulum pendidikan agama Islam, ekonomi Islam, politik Islam, hukum Islam, administrasi bangsa yang utuh serta stabilitas dan mobilisasi kekuasaan yang selalu berpihak pada pendidikan niscaya politik pendidikan Islam atau para pengambil kebijakan pendidikan Islam dapat menyusun kurikulum Pendidikan agama Islam menuju pendidikan abad XXI.

Dengan demikian dekade abad XXI melalui proses globalisasi telah menyentuh hampir seluruh aspek kehidupan yang tidak saja di bidang ekonomi Islam, bisnis Islam, budaya Islam, politik Islam, ideologi Islam, tetapi juga telah menyentuh ke tataran sistem, proces,aktor dan events. Kesimpulannya adalah masyarakat paling baik adalah masyarakat yang mempersiapkan diri untuk menghadapi abad XXI melalui pendidikan Islam, dan kualitas pemimpinnya. Dengan demikian politik pendidikan Islam yang baik adalah apabila penguasa memanfaatkan pendidikan untuk kekuasaannya hal ini terbukti bahwa politik pendidikan Islam yang baik adalah yang mampu membangun pendidikan Islam dalam menghadapi abad XXI baik melalui penyusunan kurikulum pendidikan agama Islam ataupun perbaikan ekonomi pendidikan Islam yang maju.

\footnotetext{
${ }^{14}$ Gregory Minton, M. Alayne Sullivan. Educational Justice, .....
} 


\section{Kurikulum Pendidikan Agama Islam Kerangka Pikir Para Politik Pendidikan} Islam

Ilmuwan politik atau pengambil kebijakan pendidikan Islam membutuhkan wawasan kependidikan untuk dapat menjelaskan berbagai persoalan dengan baik kepada masyarakat. Hal ini dapat dilaksanakan dengan memperkenalkan kurikulum Pendidikan agama Islam. Pada konteks inilah kita pantas optimis bahwa pada masa-masa mendatang, kajian-kajian oleh para politik pendidikan Islam adalah sangat penting dan berkembang pesat.

Proses kemunculan politik pendidikan Islam sebagai suatu bidang kajian, baik di kalangan ilmuwan politik Islam maupun ilmuwan pendidikan agama Islam telah melalui pergumulan metodologis yang panjang dan penuh perdebatan. Di satu pihak, para penggagas bidang kajian ini dengan penuh gairah menjelaskan bahwa kajian politik pendidikan Islam adalah kajian yamg penting dilakukan, baik oleh para ilmuwan politik maupun para ilmuwan pendidikan Islam.

Ditinjau dari segi politik Islam banyak hal yang mencengangkan telah terjadi dalam riwayat hidup republik ini. Baik para politisi yang langsung bermain di gelanggang maupun para ahli yang berusaha mengamati secara objektif dan netral. Mempelajari masalah proses pembaharuan atau pembangunan di bidang politik Islam memiliki standar yaitu: kualitas ketentraman, keamanan, serta kedamaian yang dirasakan oleh anggota masyarakat dalam pergaulan hidup politik. ${ }^{15}$

Hal inilah menjadi indikator bagi para politik pendidikan Islam untuk menyusun kurikulum Pendidikan Agama Islam. Kurikulum Pendidikan Agama Islam yakni kurikulum yang mensyiarkan nilai-nilai ketentraman, keamanan dan kedamaian. Beda halnya dengan politik pendidikan saat ini, kebijakan negara dalam bidang pendidikan belum menunjukkan upaya serius dalam membangun pendidikan di Indonesia. Dan belum mencapai indikator dari sudut politiknya saja sekalipun, yakni belum dinikmati oleh seluruh bangsa Indonesia kualitas pendidikan yang tentram, aman serta damai. Hal ini terbukti masih banyaknya para siswa yang tawuran, anak-anak di bawah umur korban pelecehan seksual oleh gurunya (Kasus JIS di Jakarta). ${ }^{16}$ dan bahkan sesama guru belum serius

${ }^{15}$ Alfian. Beberapa Masalah Pembaharuan Politik Indonesia, Edisi Kedua. (Jakarta: Rajawali Press, 1985), h.18.

${ }^{16} \mathrm{http}: / /$ www.liputan6.com/tag/jis 
FITR AH Jurnal Kajian Ilmu-ilmu Keislaman

Vol. 03 No. 1 Juli 2017

untuk meningkatkan kinerja dan profesionalitas mengajarnya. Sudah ada berbagai upaya, namun belum signifikan menunjukkan keseriusan itu. Carutmarutnya bangsa dengan berbagai permasalahan yang ada di dalamnya merupakan masalah bersama. Artinya, jika kita ingin melakukan perbaikan maka semua segi kehidupan harus diperbaiki. Dunia pendidikan, adalah bersentuhan dengan segala permasalahan yang ada dalam suatu bangsa. Bisa saja dunia pendidikan dituding sebagai biang dari segala permasalahan karena bagaimanapun dalam dunia pendidikanlah semua orang yang berkiprah di negeri ini digembleng. Maka tidak mengherankan kini dunia pendidikan Islam mesti diberi perhatian lebih oleh pemerintah. Dalam hal ini pemerintah selayaknya mengambil kebijakan untuk memasukkan kurikulum Pendidikan Agama Islam dalam setiap jenjang dan jenis ppendidikan sebagai mata pelajaran wajib agar peserta didik memahami apa yang boleh dan tidak. Aturan mana yang mesti dan yang didahulukan. Artinya setiap aktivitas keehidupan mempunyai saling menghidupi, saling membutuhkan, menghargai dan mempunyai apresiasi terhadap setiap potensi yang dimiliki oleh peserta didik baik di sekolah maupun di lingkungan masyarakat.

Orang-orang yang berkecimpung dalam dunia pendidikan tentu tidak mau dipersalahkan begitu saja, karena selama ini sebenarnya dunia pendidikan belum mendapat perhatian dan pembinaan secara serius. Dunia pendidikan yang sejatinya merupakan wahana strategis untuk investasi sumber daya manusia di masa depan sering justru diperlakukan tidak adil. Sebagai contoh, anggaran pendidikan $20 \%$ yang sudah dikuatkan dengan undang-undang, ternyata masih diplintir dan dipolitisir demi kepentingan politis. Jadi, sesungguhnya cukup logis jika akhirnya menurut penilaian berbagai lembaga independen tingkat dunia, kualitas pendidikan di Indonesia masih rendah, bahkan di tingkat Asia Tenggara sekalipun.

Secara umum rendahnya kualitas pendidikan di Indonesia berkaitan dengan belum adanya standarisasi yang ketat berkaitan dengan kualitas.Oleh sebab itulah pada dekade terakhir pemerintah melalui Badan Standar Nasional Pendidikan (BSNP) mulai melakukan standarisasi. Keadaan dunia pendidikan yang tanpa standar selama ini diperparah lagi dengan kecenderungan pelaksanaan pendidikan dan pengajaran yang tidak efektif dan efisien. Banyak lembaga pendidikan melaksanakan proses pembelajaran hanya sebagai formalitas, yang penting meluluskan peserta didik. Dan jika didata, 
permasalahan pendidikan di Indonesia setidaknya menyangkut beberapa hal berikut: (1). Rendahnya sarana fisik, (2). Rendahnya kualitas guru, (3). Rendahnya kesejahteraan guru, (4). Rendahnya prestasi siswa, (5). Rendahnya kesempatan pemerataan pendidikan, (6). Rendahnya relevansi pendidikan dengan kebutuhan, (7). Mahalnya biaya pendidikan, (8) Kurangnya dedikasi dan performance guru di mata siswa, (9) Karakter siswa dan guru yang belum integral.

Dengan demikian politik pendidikan Islam saat ini perlu ditata baik melalui sistem pendidikan nasional. Politik pendidikan Islam harus menjalar ke setiap lini baik dari aspek kebutuhan peserta didik serta kebutuhan negara secara mengglobal dan mendunia dan mampu menghadapi abad XXI. Politik pendidikan Islam harus mampu menghadapi krisis dari pendidikan itu sendiri yang selama ini hilang dari strukturnya. Conrad Hughes, ${ }^{17}$ menyebutkan Theory of Knowledge guide so that it might place more emphasis on certain strands of critical thinking that are currently not developed in its structure. Teori pengetahuan penting ditempatkan sehingga mungkin lebih menekankan pada alur tertentu pemikiran kritis yang saat ini tidak dikembangkan dalam strukturnya. Di mana pentingnya pengetahuan yang mampu menekankan pemikiran kritis untuk mengedepankan politik pendidikan Islam agar masalah pendidikan dapat diatasi, kurikulum Pendidikan Agama Islam dibudayakan dalam setiap kompetensi inti dan kompetensi dasar mata pelajaran.

Kurikulum Pendidikan Agama Islam merupakan model pendidikan yang berorientasi dan memandang pendidikan memusatkan peserta didik yang mempunyai potensi sesuai dengan fitrahnya. Manusia sebagai makhluk hidup, harus mampu melangsungkan, mempertahankan, dan mengembangkan hidupnya. Dalam hal ini posisi pendidikan Islam sangat diharapkan dapat membangun proses pendidikan. Dengan demikian penting membangun sikap saling menghargai hak-hak asasi manusia, seperti hak untuk berlaku dan diperlakukan dengan adil, hak untuk menyuarakan kebenaran, hak untuk berbuat kasih sayang, dan lain sebagainya. Manusia adalah individu yang rasional sebagai nilai yang tertinggi dan sumber nilai yang terakhir. Manusia

${ }^{17}$ Conrad Hughes. Theory of Knowledge aims, objectives and assessment criteria: An analysis of critical thinking descriptorsJournal of Research in International Education April 2014 13: 30-45, International School of Geneva, 62 Route de Chêne, 1208 Geneva, Switzerland. Email: conrad.hughes@ecolint.ch. 2014. 
FITR AH Jurnal Kajian Ilmu-ilmu Keislaman

Vol. 03 No. 1 Juli 2017

dianggap bukan sebagian dari alam yang statis tetapi sebagai makhluk yang kreatif. ${ }^{18}$

Untuk mencapai makhluk kreatif mestinya tertanam dalam pola pemikiran bahwa manusia merupakan titik dari alam semesta. Manusia adalah sumber norma dan secara rasional dapat menguasai dan menyusun alam tanpa konsep yang transendental. Manusia adalah ukuran dari segala-galanya dan menghormati nilai-nilai manusia yang nyata. Manusia menjadi titik tolak dan ukuran dari segala sesuatu dan dengan demikian mengakui adanya keberagaman manusia. Keberagaman peserta didik dapat disatupadukan melalui proses pendidikan dengan memberikan sejumlah mata pelajaran secara berkesinambungan dan dengan pendekatan-pendekatan Islami.

Kurikulum Pendidikan Agama Islam mengembangkan indikator tentram, aman dan nyaman sebagaimana disebutkan di atas dengan melaksanakan harapan cendekiawan muslim yang dinyatakan Azyumardi Azra didukung oleh Murthada Muthahhari dengan mengutip pernyataan Muhammad Iqbal bahwa:

Kemanusiaan saat ini membutuhkan tiga hal: Suatu penafsiran spiritual atas jagat, emansipasi spiritual atas individu, dan suatu himpunan asas yang dianut secara universal yang menjelaskan evolusi masyarakat manusia atas dasar spiritual. Eropa modern tak syak lagi telah membangun sistem-sistem idealitas pada jalur ini, tetapi pengalaman menunjukkan bahwa kebenaran yang terungkap lewat akal murni tidak mampu membawa api keyakinan hidup yang hanya bisa dibawa oleh wahyu yang bersifat personal saja. Inilah alasannya kenapa pemikiran saja telah mempengaruhi manusia semakin sedikit, sementara agama selalu meningkatkan individuindividu dan mentrasformasikan masyarakat secara keseluruhan. Hasil adalah ego yang menyeleweng, yang mencari dirinya melalui demokrasi-demokrasi saling tidak toleran yang berfungsi hanya untuk menindas yang miskin demi kepentingan yang kaya. Percayalah padaku, Eropa masa sekarang adalah hambatan terbesar di tengah jalan menuju kemajuan etis manusia. Orang-orang muslim dipihak lain, memiliki gagasan-gagasan puncak yang bersumber dari wahyu yang datang dari lubuk kehidupan yang paling dalam, menginternalisasikan ekternalitanyatanya. Baginya basis spiritualkehidupan adalah masalah keyakinan yang untuknya orang

${ }^{18}$ H.A.R.Tilaar. Perubahan Sosial dan Pendidikan (Jakarta: Rineka Cipta, 2012), h. 140. 
yang paling sedikit tercerahkan di antara kita sekalipun bisa dengan mudah mengatur hidupnya. ${ }^{19}$

Kutipan Mutthhari di atas bahwa pentingnya peserta didik yang dibekali kurikulum Pendidikan Agama Islam yakni memberikan kurikulum yang mengintegrasikan nilai-nilai kauniyah dan Ilahiyah di mana wahyu dijadikan sumber dari segala sumber internalisasi kehidupan dan keyakinan, sebagai pijakan mendasar alam mengislamisasikan ilmu-ilmu pengetahuan dan menyatukannya dengan pemikiran manusia. Hal inilah yang diupayakan ditanamkan bagi peserta didik nilai-nilai kemanusiaan dengan sejumlah ilmu dan keterampilan.

Kuntowijoyo juga menyatakan bahwa peserta didik penting juga dibekali dengan mengupayakan adanya penyatuan (bukan sekedar menggabungkan) wahyu Tuhan dan temuan pikiran manusia (ilmu-ilmu integralistik), tidak mengucilkan Tuhan (sekularisme) atau mengucilkan manusia (other worldly asceticisme). ${ }^{20}$

Kurikulum Pendidikan Agama Islam yang ditawarkan adalah menjadikan alquran dan Sunnah sebagai grand theory pengetahuan. Sehingga ayat-ayat qauliyah dan qauniyah dapat dipakai. ${ }^{21}$

Dapat disusun sebagai peta konsep bahwa kurikulum Pendidikan Agama Islam sebagimana dalam gambar berikut:

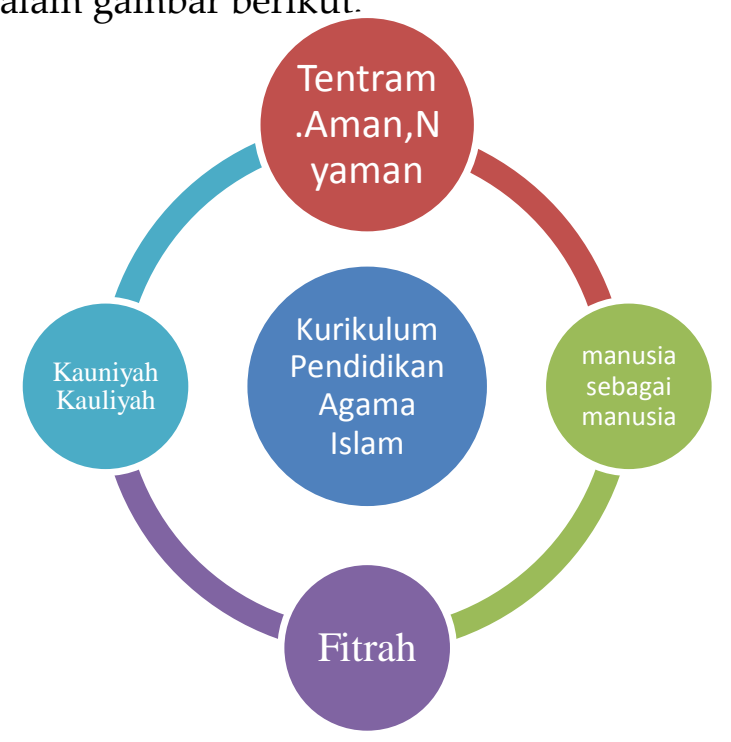
1995), h. 75.

${ }^{19}$ Murthada Muthahhari. Perspektif al-Qur'an tentang Manusia dan Agama (Bandung:Mizan, ${ }^{20}$ Kuntowijoyo. Islam Sebagai Ilmu, Cet. II (Jakarta: Penerbit: Teraju, 2005), h.57-58.

${ }^{21}$ Imam Suprayogo. Zainal Abidin Bagir, (ed), Membangun Integrasi Ilmu dan Agama (Malang: UIN Malang, 2005), h.49-50. 
FITR AH Jurnal Kajian Ilmu-ilmu Keislaman

Vol. 03 No. 1 Juli 2017

\section{Politik Pendidikan Islam Dalam Menghadapi Abad Xxi}

Kualitas pendidikan di Indonesia pada saat ini boleh dibilang amat memprihatinkan. Data UNESCO membuktikan bahwa peringkat Indeks Pengembangan Manusia (Human Development Index) Indonesia makin menurun. Di antara 174 negara di dunia, Indonesia menempati urutan ke-102 (1996), ke-99 (1997), ke-105 (1998) dan ke-109 (1999). Dan menurut survey Political and Economic Risk Consultant (PERC), kualitas pendidikan di Indonesia berada pada urutan ke-12 dari 12 negara di Asia. Sedang data Balitbang menunjukkan kenyataan bahwa dari 146.052 Sekolah Dasar di Indonesia ternyata hanya ada delapan sekolah yang mendapat pengakuan dunia dalam kategori The Primary Years Program (PYP). Dari 20.918 SMP di Indonesia hanya delapan sekolah yang mendapat pengakuan dunia dalam kategori The Middle Years Program (MYP) dan dari 8.036 SMA hanya tujuh sekolah yang mendapat pengakuan dunia dalam kategori The Diploma Program. 22

Melalui kondisi pendidikan Indonesia tersebut adalah sangat riskan di mata dan di telinga kita bahwa sesungguhnya pendidikan Islam belum mampu memposisikan dirinya untuk menjadi harapan pendidikan itu sendiri sebagaimana diketahui bahwa pendidikan merupakan kerja membangun manusia supaya dia bisa survive melindungi diri terhadap alam serta mengatur hubungan antar-manusia. ${ }^{23} \mathrm{Hal}$ ini menunjukkan tidak adanya terbangun pada diri peserta didik. Basis Pendidikan Agama Islam berawal dari diri sendiri yang harus digali potensinya di dunia pendidikan Islam itu sendiri. Untuk ini penting disusun kurikulum Pendidikan Agama Islam guna mengakui dan menyadarkan setiap insan betapa pentingnya menghargai potensi diri masing-masing individu. Setiap generasi baru pada gilirannya akan menggali dan mengembangkan pengetahuan dan kecakapan baru yang diperlukannya untuk merespon dan mengatasi tantangan yang tidak dikenal lewat pendidikan pengetahuan dan kecakapan terdahulu.

Dengan demikian pendidikan pada dasarnya merupakan sarana proses, proses pemberdayaan, dan sosialisasi, dalam kerangka mana terjadi proses pembangunan manusia yang inovatif, berdaya kritik, berpengetahuan,

${ }^{22}$ Manik F. Suseno. Pendidikan di Indonesia: Masalah dan Solusinya. Dari http://www.mii.fmipa.ugm.ac.id. 2006 Diakses pada 13 Desember 2010.

${ }^{23}$ Sigmund Freud. Das Unbehagen in der Kultur, Frankfurt/Main: Fischer Taschenbuch Verlag (Pertama terbit, 1930, Jerman: Reprint, 2007), h. 55-56). 
berkepribadian, dan taat azas. ${ }^{24}$ Dalam konteks abad XXI, pendidikan Islam harus mampu mempertahankan budaya dan jati diri bangsa di tengah-tengah gencarnya gempuran beragam budaya dan peradaban bangsa lain. Indonesia harus jeli tehadap politik pendidikan Islam. Politik pendidikan Islam melahirkan kebijakan-kebijakan baru di bidang pendidikan yang mewakili ideologi dan filosofi suatu bangsa sehingga bangsa terdidik dan tergerak untuk menghadapi abad XXI sebagai bukti adanya upaya dan cara untuk memikirkan bangsa ini tidak lagi memiliki kualitas standar rendah.

Untuk itu tepat yang dituliskan Sirozi bahwa:

Cara kita berfikir mengenai pembentukan kebijakan pendidikan terkait dengan pandangan ideologis dan filosofis kita, tidak saja sehubungan dengan pendidikan, tetapi juga dengan hakikat masyarakat madani. Secara lebih khusus mereka terkait dengan dengan kepercayaan kita mengenai cara bagaimana keputusan pendidikan harus dibuat dan diterapkan. Dengan demikian kajian tentang kebijakan merupakan bidang yang sangat diperebutkan. ${ }^{25}$

Dengan demikian wawasan, insight setiap ilmuwan pendidikan dalam memerankan politik pendidikan Islam seharusnyalah selalu berpolakan ideologis dan filosofis bangsa. Kuatnya landasan bangsa dalam setiap memutuskan kebijakan pendidikan maka perubahan yang terjadi di masyarakat Indonesia dalam dunia abad XXI pun dapat teratasi. Misalnya perubahan radikal dan dalam berbagai aspek kehidupan masyarakat membutuhkan perhatian yang cermat oleh para pelaku dan pengambil keputusan di pemerintahan. Salah menilai, menyusun, dan mengembangkan kebijakan akan berakibat fatal terhadap laju pertumbuhan sebuah negara dan berakibat fatal bagi politik pendidikan Islam bangsa. Dari seluruh komponen dan aspek pertumbuhan yang ada, manusia merupakan faktor yang terpenting karena merupakan pelaku utama dari berbagai proses dan aktivitas kehidupan dalam memutuskan kebijakan pendidikan Islam. Oleh karena itulah maka para pengambil kebijakan yang include dalam politik pendidikan Islam sebaiknya memiliki karakteristik menghadapi abad XXI sebagai berikut:

${ }^{24}$ Zainuddin \& Imam Buchori. "Pokok Pokok Pikiran Dalam Membangun Budaya dan Karakter Bangsa". (Disampaikan dalam Sarasehan Nasional: Pengembangan Pendidikan Budaya dan Karakter Bangsa, diselenggarakan oleh DIKTI tanggal 7 April 2010 di Bandung.)

${ }^{25}$ M. Sirozi. Politik Pendidikan, Dinamika Hubungan antara Kepentingan Kekuasaan dan Praktik Penyelenggaraan Pendidikan(Jakarta: Grafindo Persada, 2004), h.212. 
FITR AH Jurnal Kajian Ilmu-ilmu Keislaman

Vol. 03 No. 1 Juli 2017

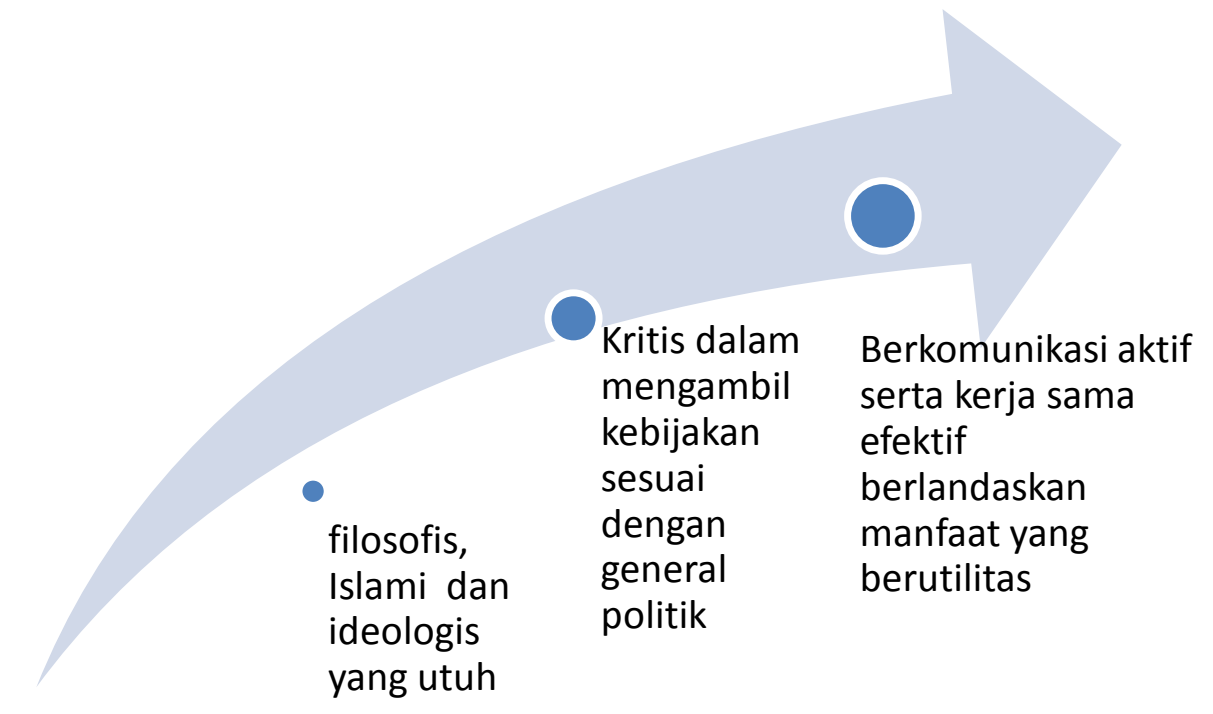

\section{PENUTUP}

Pendidikan Islam sesungguhnya sudah tertata, akan tetapi pada tahap implementasinya sangat dipengaruhi oleh banyak aspek. Pemerintah juga telah melakukan berbagai pembaharuan, baik melalui kebijakan-kebijakan pendidikan Islam termasuk reformasi pendidikan Islam. Berbagai pembaruan tersebut merupakan upaya menyiapkan bangsa Indonesia agar mampu mengembangkan kehidupan demokratis yang mantap dalam memasuki era globalisasi dan informasi menghadapi abad XXI.

Abad XXI adalah abad yang melibatkan setiap lapisan masyarakat dalam berbangsa dan bernegara mempunyai ketertarikan untuk mengikutinya. Untuk itu setiap warga pendidikan senantiasa tanggap terhadap isu-isu di dalam dan luar negeri merupakan tantangan yang harus dipertimbangkan dalam membangun sistem pendidikan nasional. Oleh sebab itu pemerintah pusat maupun daerah, dalam hal ini Kementerian Pendidikan Nasional dan Kementerian Agama harus mampu dengan cepat menjawab tantangantantangan pada abad XXI untuk direalisasikan dalam program pendidikan nasional melalui kebijakan-keijakan yang tepat.

Kurikulum Pendidikan Agama Islam berfungsi mengembangkan kemampuan dan membentuk watak serta peradapan bangsa yang bermartabat dalam rangka mencerdaskan kehidupan bangsa, bertujuan untuk mengembangkan potensi peserta didik agar menjadi manusia yang beriman dan bertakwa kepada Tuhan yang Maha Esa, berakhlak mulia, sehat, berilmu, cakap, kreatif, mandiri, dan menjadi warga Negara yang demokratis serta bertanggung jawab sehingga terwujud sistem pendidikan yang berkualitas. Hanya tatkala 
sampai pada implementasi menjadi sangat berbeda dengan idealisme. Karena dunia pendidikan kita masih rentan disusupi kepentingan lain.

Politik pendidikan Islam mesti dibesarkan dan digaungkan dalam setiap aktivitas kehidupan khususnya dalam mengambil setiap kebijakan pendidikan Islam. Politik pendidikan Islam diupayakan dijadikan sebagai instrumen dalam menyikapi setiap aktivitas pendidikan agar pendidikan mudah dipahami dan dilaksanakan setiap warga pendidikan. Politik pendidikan Islam dijadikan sebagai landasan filosofis dan ideologis dalam menjalankan aktivitas pendidikan untuk menyusun kurikulum Pendidikan Agama Islam.

Kurikulum Pendidikan Agama Islam merupakan model pendidikan yang berorientasi dan memandang manusia sebagai manusia makhluk ciptaan Tuhan dengan fitrahnya. Manusia sebagai makhluk hidup, harus mampu melangsungkan, mempertahankan, dan mengembangkan hidupnya. Dalam hal ini posisi pendidikan sangat diharapkan dapat membangun proses pendidikan yang berbasis islami. Dengan demikian penting membangun sikap saling menghargai hak-hak asasi manusia, seperti hak untuk berlaku dan diperlakukan dengan adil, hak untuk menyuarakan kebenaran, hak untuk berbuat kasih sayang, dan lain sebagainya. Manusia adalah individu yang rasional sebagai nilai yang tertinggi dan sumber nilai yang terakhir. 
FITR AH Jurnal Kajian Ilmu-ilmu Keislaman

Vol. 03 No. 1 Juli 2017

\section{DAFTAR PUSTAKA}

Alfian, Beberapa Masalah Pembaharuan Politik Indonesia, Edisi Kedua. Jakarta: Rajawali Press. 1981.

Badan Standar Nasional Pendidikan. Versi 1.0 - Tahun 2010. Paradigma Pendidikan Nasional Abad XXI.Jakarta: BSNP.

Daun, Hoger. Reza Arjmand \& Geoffrey Walford. (Chapter One).Muslims and Education In a Global Context. Educational Strategies Among Muslims In The Context Of Globalization Some National Case Studies, Volume 3, ISBN. 9004136754. Boston:Brill Leiden. 2004.

Freud, Sigmund. Das Unbehagen in der Kultur, Frankfurt/Main: Fischer Taschenbuch Verlag, REPRINT. (Pertama terbit, 1930). 2007.

Gregory Minton \& M. Alayne Sullivan, Educational Justice, Transformative Leadership Practices, and Special Needs Students International Journal of Education ISSN 1948-5476 Vol. 5, No. 4, www.macrothink.org/ije 190. 2013.

Hefner, Robert.W. Making Modren Muslims. The Politics Of Islamic Education In Southeast Asia. Honolulu: University Of Hawai'i Press. 2009.

Hughes, Conrad. Theory of Knowledge aims, objectives and assessment criteria: An analysis of critical thinking descriptorsJournal of Research in International Education April 2014 13: 30-45, International School of Geneva, 62 Route de Chêne, 1208 Geneva, Switzerland. Email: conrad.hughes@ecolint.ch. 2014.

IBRD, The Challenge of Development. World Development Report. 1991.

Kasus JIS di Jakarta. (http://www.liputan6.com/tag/jis). 2014.

Kasus putri tukang becak dapat IPK: 3,96, Universitas Negeri Semarang Jurusan Akutansi memperoleh beasiswa ke Inggris yang diberikan Presiden RI Susilo Bambang Yudoyono).14 Juni 2014. (http://bit.ly/1n8Enay).

Kennedy. Paul (Terj). Menyiapkan Diri Menghadapi Abad Ke-21, Jakarta: Yayasan Obor Indonesia,hlm. XIV. 1995.

Manik, F. Suseno. Pendidikan di Indonesia: Masalah dan Solusinya. darihttp://www.mii.fmipa.ugm.ac.id. Diakses pada 13 Desember 2010. 2006. 
McGlynn, Frank \& Athur Tuden. Pendekatan Antropologi pada Perilaku Politik. Jakarta. UIP Press. 2000.

Muahaimin. Yahya\& Colin MacAndrews. Masalah-Masalah Pembangunan Politik. Yogyakarta: Gadjah Mada University Press. 1995.

Okezone, Lulus Sarjana, Penjual Gorengan Bawa Dagangannya Saat Wisuda, diterbitkan 15 Februari 2017.

Riddel, A.R. 1998. Reforms of educational efficiency and equity in developing countries: An overview. Compare, 28 (3), 227-292.The International Education Journal:Comparative Perspectives, Volume 6 Number 1 March 2005Published by Shannon Research Press Adelaide, South Australia ISSN 1443-1475 http://iej.cjb.net

Rush, Michael. \& Phillip Althoff. Pengantar Sosiologi Politik. Jakarta: Rajawali Press. 1990.

Sirozi. M. Politik Pendidikan, Dinamika Hubungan antara Kepentingan Kekuasaan dan Praktik Penyelenggaraan Pendidikan, Jakarta: Grafindo Persada. 2010.

Zainuddin, Imam Buchori. "Pokok Pokok Pikiran Dalam Membangun Budaya dan Karakter Bangsa". (Disampaikan dalam Sarasehan Nasional: Pengembangan Pendidikan Budaya dan Karakter Bangsa, diselenggarakan oleh DIKTI tanggal 7 April 2010 di Bandung.) 2010. 
FITR AH Jurnal Kajian Ilmu-ilmu Keislaman

Vol. 03 No. 1 Juli 2017

Strategi Pendidikan Islam Di Era Digital

\section{NURYADIN}

